\title{
A histochemical study of various forms of cerebral lipidoses
}

\author{
M. WOLMAN \\ From the Department of Pathology, Government Hospital, Tel-Hashomer, Israel
}

SYNOPSIS A histochemical study was made of 13 cases of lipidoses of the central nervous system? Niemann-Pick's disease can be differentiated from other cerebral lipidoses by the finding that altr affected cells store histochemically stainable phospholipids. Evidence has been adduced indicatin 8 that the material stored in infantile amaurotic idiocy is a complex containing ganglioside, cholesterol and possibly other constituents. The non-infantile forms of amaurotic idiocy were found to diffeo in essential points from the classical infantile form.

Most cases of cerebral lipidoses belong to the group of cerebromacular degenerations which includes the various types of amaurotic idiocy and NiemannPick disease. Classification and understanding of these disease processes have been hampered by lack of adequate criteria for distinguishing between the various diseases. Clinical and pathological data led to classification of cases of amaurotic idiocy in accordance with the age at onset, age at death, and the length of time between onset and death. The same criteria led some authors who studied cases of Niemann-Pick's disease with involvement of the nervous system to describe them as mixed cases of amaurotic idiocy with Niemann-Pick's disease.

Chemical studies have helped to determine the nature of the lipid moiety which was most severely deranged and to use this as a diagnostic criterion; but as most chemical studies were performed on relatively large pieces of tissue, two difficulties arose: 1 , In most cases of lipidoses more than one lipid was abnormal in amount; 2 , in some cases the 'dilution' of affected cells by normal or secondarily changed, e.g., demyelinated, tissue obscured the findings and the diagnosis.

The histochemical approach, and especially if coupled with a quantitative chenical study, may obviate some of these difficulties. Although far from perfect from the chemical standpoint, histochemistry can show positively the sites of the abnormal metabolites.

The following is a histochemical study of the central nervous system in 13 cases of lipidoses. It indicated that lipid complexes rather than pure lipids are deposited in the cells and allowed certaing conclusions to be drawn in relation to the classificar tion of these diseases.

\section{MATERIAL AND METHODS}

This study is based on formalin-fixed material. ThD length of fixation varied from over 30 years to a few days. The material was in part derived from this labora $\overrightarrow{\vec{B}}$ tory. Professor F. Feyrter of Vienna (previously fron Vienna, Graz, and Goettingen) also sent samples of tissues. from various cases, some of which had been previousl\$ reported in the literature. Dr. R. M. Norman of Bristof sent samples of tissues from three other cases. Pieces froro a brain of another case were given by Dr. S. A. Reif an U. Sandbank from the Assaf Harofe Government Hospital in Israel.

Seven of the cases were of the infantile type of amauro3 tic idiocy and three were of Niemann-Pick's disease Three further cases were of other than infantile forms of amaurotic idiocy. One was a case of amaurotic idioc with visceral involvement described by Norman Urich, Tingey, and Goodbody (1959). The second was of late infantile amaurotic idiocy described by Tinges, Norman, Urich, and Beasley (1958). The third was case of atypical amaurotic idiocy described by Wolma (1961).

All histochemical staining procedures were done oub frozen sections. The staining procedures employed and the findings in the various cases are summarized in the Table.

\section{DISCUSSION}

The findings of this study as summarized in the Table allow three conclusions to be drawn and these will de discussed separately. 
TABLE

HISTOCHEMICAL REACTIONS OF THE MATERIAL STORED IN NEURONES

$\begin{array}{lllll}\begin{array}{l}\text { Seven Cases of } \\ \text { Infantile Amauro- }\end{array} & \begin{array}{l}\text { Case Described } \\ \text { by Norman et al. } \\ \text { tic Idiocy }\end{array} & \begin{array}{l}\text { Case Described } \\ \text { by Wolman } \\ (1959)\end{array} & \begin{array}{l}\text { Case of Late } \\ \text { Infantile Amauro- } \\ \text { tic Idiocy } \\ \text { Described by } \\ \text { Tingey et al. (1958) }\end{array} & \begin{array}{l}\text { Three Cases of } \\ \text { Niemann-Pick's } \\ \text { Disease }\end{array} \\ \end{array}$

Chemical and pathological data

Lipids

Sudan IV

Sudan black

Serra's procedure for bound lipids

Baker's procedure for phospholipids

Luxol

Schultz

Performic acid-Schiff

Solubility in chloroform methanol

$(2: 1)$

Carbohydrates and acidic groups

P.A.S.

Colloidal iron

Einschlussfaerbung Orthochromatic

Orcinol Metachromatic

Proteins

Millon

Ninhydrin-Schiff

Danielli's tetrazo method

\begin{tabular}{|c|c|}
\hline $\begin{array}{l}\text { Death in infancy; } \\
\text { no storage in } \\
\text { internal organs }\end{array}$ & $\begin{array}{l}\text { Death in infancy; } \\
\text { storage of lipid } \\
\text { in parenchymatous } \\
\text { organs }\end{array}$ \\
\hline
\end{tabular}

Death at age of $2 \frac{1}{2}$ years; no information available about storage in internal organs

Death at age of
$4 \frac{1}{2}$ years; storage
of lipid in internal
organs

Death in infancy : storage of lipids in parenchymatous organs organs
0

$\pm \quad+++$

$\pm$

0

$0-+i$

$\begin{array}{ll}+-+++ & ++ \\ + & 0 \\ +-++ & ++ \\ +-++ & 0 \\ 0-++ & 0\end{array}$

$\mathbf{0}$

0 $+t$

$\pm$

$+t+$

$\pm$

$0^{++}+$

$0 \pm$

0

0

$$
++t
$$

$+++$

$\mathbf{0}-+++$

$+++$

0

$+++$

o

$0^{+++}$
++
++

$\pm$

$++$

$\begin{array}{lll} \pm & +++ & 0- \pm \\ \pm & +++ & 0- \pm \\ 0 & ++ & 0- \pm\end{array}$

DIFFERENTIATION OF NIEMANN-PICK'S DISEASE FROM AMAUROTIC IDIOCY In many cases of amaurotic idiocy phospholipids demonstrable by the Baker procedure, or earlier by the Smith-Dietrich procedure, are found in the affected neurones. Their amount is variable from one cell to another and some cells do not contain demonstrable amounts of phospholipids. The variability in the amounts of phospholipids in the different cells in single cases of amaurotic idiocy is believed to represent an important diagnostic criterion, as storing cells in NiemannPick's disease always contain high concentrations of phospholipids. The validity of this criterion is also borne out by the generally accepted concepts about the nature of these diseases. Niemann-Pick's disease is a sphingomyelin storage disease and each one of the cells affected by the process stores the 'specific' lipid. In amaurotic idiocy phospholipids represent 'non-specific' additionally stored lipids.

'NON-SPECIFIC' STORED COMPONENTS AND THEIR SIGNIFICANCE The Table shows that the material stored in the infantile cases of amaurotic idiocy always contains cholesterol in appreciable amounts. This finding, previously noted by other observers, e.g., Diezel (1957), indicates that there is no more reason to regard infantile amaurotic idiocy as a storage disease of gangliosides than to regard it as a cholesterolosis. The fact that chemical analysis showed the ganglioside storage and did not show the presence of increased amounts of cholesterol is probably related to the high content of cholesterol in the normal brain, so that increased amounts, in order to be apparent, have to be high enough to compensate for the dilution effect of surrounding tissue. Furthermore, amaurotic idiocy is often associated with secondary demyelinating changes in the white matter and the resulting loss of cholesterol may have often overcompensated for the increased cholesterol content in the neurones.

The constant presence of cholesterol in the cells of infantile amaurotic idiocy and the finding that the lipids are better stained by Serra's (1958) procedure for bound lipids (in which electron bonds between lipids and other constituents are split by urea) than by the simple Sudan black technique indicate that the material deposited in the affected cells is not a mixture of lipids but rather a complex which consists of gangliosides, cholesterol, and probably other constituents. The findings of Terry and Korey (1960) of membranous cytoplasmic granules in these cells also suggest that an organized complex containing 


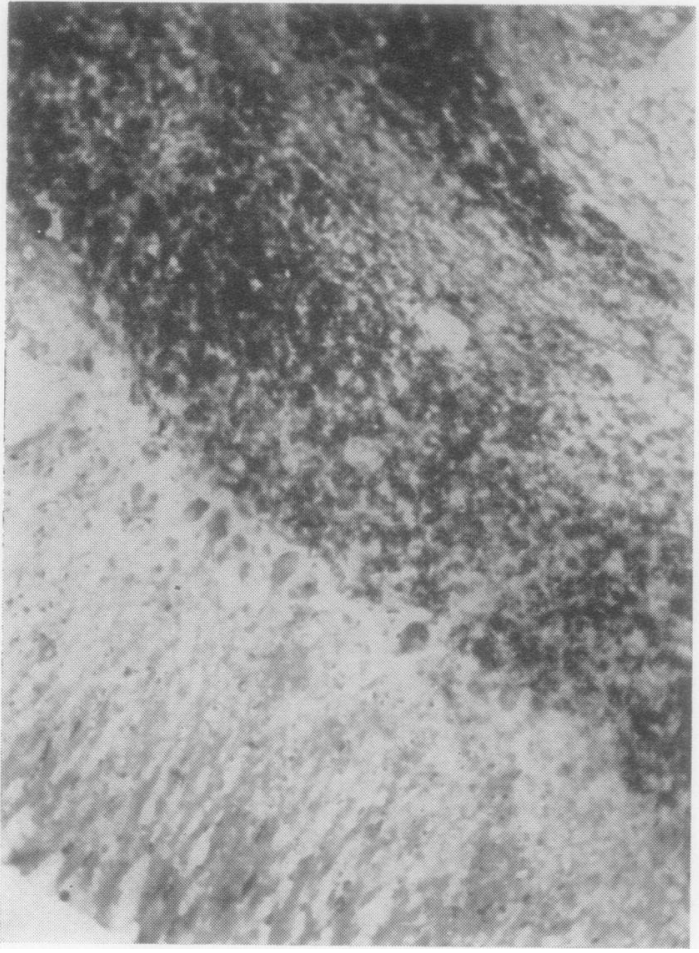

FIG. 1

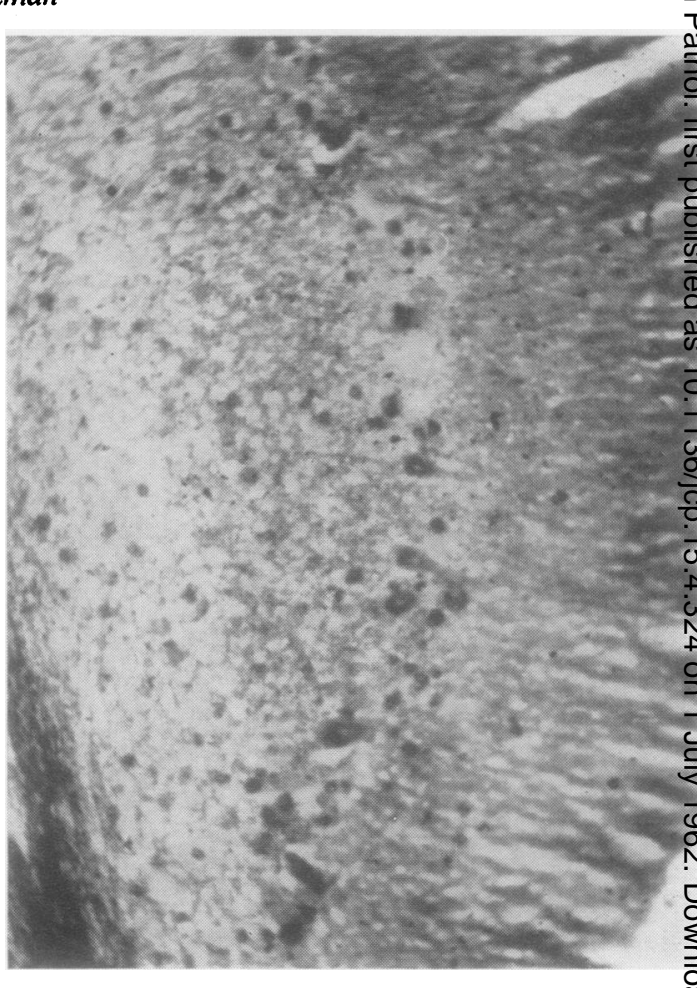

FIG. 2

FIG. 1. Frozen section of cerebellum of a case of infantile amaurotic idiocy stained with Sudan black B. The materiä stored in the cells did not stain intensely. $\times 105$.

FIG. 2. Frozen section of the cerebellum of the same case stained by Serra's procedure. The treatment with urea markedR, increased the sudanophilia of the stored material. $\times 105$.

lipids and other constituents is deposited in infantile amaurotic idiocy. It is suggested therefore that this disease is not a pure ganglioside storage disease, but a disease in which a complex containing ganglioside and cholesterol (? lipoprotein) is stored in the diseased cells. It is further suggested that the increase in 'non-specific' lipids in the various lipidoses, stressed by Uzman (1958), may in some instances represent the presence of lipidcomplexes rather than deposition of pure lipids.

RELATIONSHIP OF OTHER FORMS OF AMAUROTIC IDIOCY TO INFANTILE FORM Gangliosides are strongly acidic lipids which stain metachromatically and can bind colloidal iron. The absence of metachromatic staining in the non-infantile cases of amaurotic idiocy studied might indicate either that little or no gangliosides are present in the stored cells, or that the gangliosides are firmly bound to other components. As orthochromatic staining was observed it suggests that acidic groups are present but apparently not in a well-ordered fashion, which allows a polymerization effect of the dye molecules and it is therefore probable that the non-infantie cases of amaurotic idiocy do not store gangliosides This conclusion is borne out by chemical analyses (Tingey et al., 1958).

The cells of the non-infantile cases were found contain stainable amounts of protein, whereas the amount of protein in the stored material in infantif cases was too small for histochemical detectiono Another difference between the material stored ior the older cases and that stored in the infantile form was the presence in the older cases of stainabE amounts of unsaturated lipids.

These findings indicate that whereas typicat infantile amaurotic idiocy is probably a sing $\overrightarrow{\underline{e}}$ nosological entity, the atypical forms and the nores infantile cases represent a series of processes which basically differ from the infantile form. As the nop infantile forms differ from the infantile forms (Tay Sachs) in the clinical course, in the age at onset, 临 
the racial distribution, and in the nature of the stored substances, they should be regarded as different diseases.

I am grateful to Professor Feyrter, Dr. Norman, and Dr. Reif for the materials kindly sent. The skilful technical assistance of Mr. Sh. Weinstock is gratefully acknowledged.
REFERENCES

Diezel, P. (1957). Die Stoffwechselstörungen der Sphingolipoide. Springer, Berlin.

Norman, R. M., Urich, H., Tingey, A. H., and Goodbody, R. A. (1959). J. Path. Bact., 78, 409.

Serra, J. A. (1958). Science, 128, 28.

Terry, R. D., and Korey, S. R. (1960). Nature (Lond.), 188, 1000.

Tingey, A. H., Norman, R. M., Urich, H., and Beasley, W. H. (1958). J. ment. Sci., 104, 91.

Uzman, L. L. (1958). A.M.A. Arch. Path., 65, 331.

Wolman, M. (1961). Acta neuropath. (Berl.), 1, 73.

\section{The May 1962 Issue}

\section{THE MAY 1962 ISSUE CONTAINS THE FOLLOWING PAPERS}

Distribution of alkaline phosphatase in serum protein fractions N. H. KORNER

Distribution of alkaline phosphatase in the serum proteins in hypophosphatasia N. H. KORNER

Cerebrospinal fluid protein fractions in health and disease c. J. BRACKENRIDGE

Hypernatraemia in cerebral disorders W. H. TAYLOR

The determination of cholesterol in serum by persulphuric acid oxidation R. N. BEALE and D. CROFT

The 'fibrinolytic potential' as a simple measure of spontaneous fibrinolysis R. CHAKRABARTI and G. R. FEARNLEY

Frequency of serotypes of Streptococcus pyogenes in different diseases E. S. MITCHELL

Clinical, virological, and pathological findings in a fatal case of $Q$ fever endocarditis I. C. FERGUSON, J. E. CRAIK, and N. R. GRIST

A system of air recirculation and antibacterial surface treatment in a surgical ward G. A. J. AYLIFFE and M. A. BEARD

Pasteurella haemolytica var. urea from human sputum D. M. JONES and P. M. O'CONNOR

Mercury sensitivity of staphylococci SUSAN M. GREEN
Coagulase-negative strains of staphylococcus possessing antigen 51 as agents of urinary infection A. TORRES PEREIRA

The total cellularity of the bone marrow in man W. J. HARRISON

Reticulocyte release factor HILLAS SMITH

Two cases of aplastic anaemia associated with tumours of the thymus R. D. S. BARNES and P. O'GORMAN

Urinary excretion of histidine derivatives in megaloblastic anaemia and other conditions and a comparison with folic acid clearance test I. CHANARIN, MYRA C. BENNETT, and VALERIE BERRY

Changes in serum vitamin $B_{12}$ levels in patients with megaloblastic anaemia treated with folic acid S. JOHNSON, S. P. SWAMINATHAN, and S. J. BAKER

Observations on glial inclusion bodies in a case of acute disseminated sclerosis E. J. FIELD, HENRY MILLER, and DOROTHY S. RUSSELL

The use of plastic tubing in roller pumps M. $P$. WRIGHT and G. C. SPENCER

\section{Technical methods}

Separation of haemoglobins Lepore and $\mathbf{H}$ from $\mathbf{A}$ and $A_{2}$ in starch or acrylamide gels buffered with tris-E.D.T.A. c. C. CURTAIN

A portable water-bath for use when investigating the coagulation mechanism E. B. MITCHELL

Copies are still available and may be obtained from the PUBLISHING MANAGER, BRITISH MEDICAL ASSOCIATION, TAVISTOCK SQUARE, W.C.I, price 17s. 6D. 